\title{
ANEMIA IN GYNECOLOGY AND PERINATOLOGY - NEW ATTITUDES
}

\author{
Dragana Radović-Janošević1,2, Hristina Čolovićc, ${ }^{3,4}$ Jelena Milošević-Stevanović1,2, \\ Jelena Seratlić1,2, Dane Krtinićs ${ }^{5,6}$
}

\begin{abstract}
Anemia is a global health problem. Among women, it is present in $38 \%$ of pregnant women and $29 \%$ of non-pregnant women. The most common form is sideropenic anemia. The most common cause of anemia in gynecology is abnormal uterine bleeding that occurs as acute, chronic and intermittent bleeding. In perinatology, there are specific changes at the level of the cardiovascular and hematopoietic systems of a pregnant woman, which impose different criteria for the diagnosis of anemia relative to a non-circulating condition. The basic change is an increase in blood volume that grows more at the expense of plasma versus erythrocyte volume. The erythrocyte volume grows by about 33\%, and so does the reticulocyte count. There are two basic approaches to anemia diagnosis - a kinetic approach that seeks to determine the mechanism that led to anemia and a morphological approach that divides anemia relative to the size of the erythrocyte's mean volume and reticulocyte response. The therapy for most common - sideropenic anemia is performed with iron preparations (chemical, divalent and trivalent iron). In pregnancy, it is necessary for all pregnant women, but only in moderate doses. The total antenatal increase should be about $1000 \mathrm{mg}$. To meet these needs, $4 \mathrm{mg}$ of iron per day is needed in the first half of pregnancy and 6-7 $\mathrm{mg}$ in the second half. Due to the poor tolerance of iron, its compliance is estimated at $50 \%$.
\end{abstract}

Acta Medica Medianae 2020;59(3):84-89.

Key words: anemia, gynecology, perinatology

\footnotetext{
${ }^{1}$ University of Niš, Faculty of Medicine, Department of Obstetrics and Gynecology, Niš, Serbia

${ }^{2}$ Clinic of Obstetrics and Gynecology, Clinical Center Niš, Niš, Serbia

${ }^{3}$ University of Niš, Faculty of Medicine, Department of Physical Medicine and Rehabilitation, Niš, Serbia

${ }^{4}$ Clinic of Physical Medicine and Rehabilitation, Clinical Center Niš, Niš, Serbia

${ }^{5}$ University of Niš, Faculty of Medicine, Department of

Pharmacology and Toxicology, Niš, Serbia

${ }^{6}$ Clinic of Oncology, Clinical Center Niš, Niš, Serbia
}

Contact: Dane Krtinić

81 Dr Zoran Djindjić Blvd., 18000 Niš, Serbia

E-mail: dane.krtinic@medfak.ni.ac.rs

\section{Introduction}

Abnormal uterine bleeding can lead to anemia of gynecological origin.

The FIGO classification of abnormal uterine bleeding (AUB) "PALM-COEIN" system of classification an acute abnormal uterine bleeding, an episode of excessive menstrual blood loss which demands urgent intervention occurs independently or in the context of a chronic abnormal uterine bleeding cases (1).

$\diamond$ Chronic abnormal uterine bleeding - abnormal by volume, periods of occurrance and duration, is a disorder which lasts at least six months.

$\diamond$ Intermenstrual abnormal uterine bleeding occuring between clearly defined menstrual cycles.

$\diamond$ PALM - objective structural patterns, which can be measured and visualised by diagnostic technics such as ultrasound and/or PH analysis:

1. Polyps

2. Adenomyosis

3. Leiomyomas

4. Malignancy / Hyperplasia

COEIN

1. Coagulopathies

2. Ovulatory disorders

3. Endometrial disorders

4. Iatrogenic patterns

5. Unclassified patterns

\section{Changes of the Hematological system in pregnancy}

1. Growth of the blood volume - the volume of plasma is higher, the erythrocyte count is less and yet the erythrocyte volume grows by about 33\% $450 \mathrm{ml}$. The reticulocytes show growth. 
2. Atrial Natriuretic Peptid (ANP) - There is a growth of renal perfusion and glomerular filtration, less renal secretion, lessens the basal release of aldosterone from the glomerular zone.

3. Brain Natriuretic Peptid (BNP) - a very potent vasodilator is being created and is secreted in the amnionic cells (2).

Blood loss in vaginal birth is $500 \mathrm{ml}$ and in sectio Caesarean is $1000 \mathrm{ml}$.

1. Iron ( $\mathrm{Fe}$ ) needs in a normal pregnancy are enlarged for production $450 \mathrm{ml}, \mathrm{Er}-500 \mathrm{mg}$.

2. Total antepartum increase of $\mathrm{Fe}$ is $1000 \mathrm{mg}$.

3. Day loss of Fe in absense of bleeding is 0.5 $-1 \mathrm{mg}$.

4. Foetus needs

5. The total Fe needs are:

- For the placenta and the fetus, $300 \mathrm{mg}$

- For Er growth, $500 \mathrm{mg}$

6. The amount of $\mathrm{Fe}$ needed to fulfill the normal fetus needs and the increase of volume of maternal circulation is $800 \mathrm{mg}$.

7. The amount of Fe lost during a normal menstrual cycle is $25 \mathrm{mg}$

8. The absorbtion rate from Fe supplements is $10-20 \%$, i.e., $12 \mathrm{mg}$ a day

9. The amount of $\mathrm{Fe}$ in $1 \mathrm{ml}$ of $\mathrm{Er}$ is $1.1 \mathrm{mg}$

10. The milk absorbs Fe during lactation about $1 \mathrm{mg}$ a day (3).

\section{Cardiovascular changes during pregnancy}

Pulsation rate increases, as does the volume and pulsatory volume, renal angiotensine or aldosterone, while there is a decrease in the arterial pressure, vascular resistance systemic, $21 \%$ and pulmonary, $34 \%$ (4).

The following tables give the corresponding values of individual blood parameters by trimester of pregnancy $(5,6,7,8)$.

The total amount of iron ( $\mathrm{Fe}$ ) in the organism of an adult human is $3.5-4 \mathrm{~g}$. It is a toxic metal however, the toxic effect is detained by the formation of iron - proteins compound. The proteins which contain iron are divided into proteins that contain heme and heme binding iron, such as hemoglobin, myoglobin, cytochromes and other, and to those which do not contain heme and yet bind iron, such as ferritin, transferrin, and flavoproteins. Referring to these proteins, iron has a key role in transporting oxygen and in the energy metabolism (9).

The digested $\mathrm{Fe}$ is absorbed in the organism in a bivalent form in the duodenum and in the upper jejunum with the help of apoferritin protein, which is reversibly bound to Fe. As the amount of apoferritin is limited, resorption of $\mathrm{Fe}$ is limited to mucose blockage. The digested trivalent form and the Fe component bound to heme in the form of $\mathrm{Fe}^{3+}$ has to be reduced with the help of vitamin $C$ in its bivalent form. About $1 \mathrm{mg}$ of Fe is resorbed daily, which after entering the mucose cells as $\mathrm{Fe}^{2+}$ is bound to transportive supstances. Before entering the plasma, oxidation occurs in $\mathrm{Fe}^{3+}$ with the help of ceruloplasmin and it sticks to transferrin.
The transport of the $\mathrm{Fe}$ ions in the plasma happens via the iron-transferrin complex. As it happens, only two trivalent ions of Fe can be bound to one molecule of transferrin protein. The Fe serum is almost completely tied to transferrin. Transferrin siderophilin is the transportive protein of iron in the plasma and it is coded with the TF gene. It conducts the transport of iron from the place of absorption and the place of resorption to the place of storage in the bone marrow and partially in the liver. There, iron binds to apoferrin. Transferrin is usually saturated with $30 \%$ iron. The amount of iron in the transferrin of plasma is in balance with the iron in these stored forms in the gastrointestinal tract and in the reticuloendothelial (RES) system (10).

There is no ferritin in plasma, but there is apoferritin. In the process of creation of ferritin from apoferritin, first of all, the $\mathrm{Fe}^{2+}$ connects to the surface of the inner membrane of the apoferrin and then via oxidation it transforms into $\mathrm{Fe}^{3+}$ which binds itself tightly to the ferritin. Reduction releases it from the ferritin in the form of $\mathrm{Fe}^{2+}$.

Iron enters the structure of porphyrin and builds heme - hemoglobin, myoglobin.

\section{Erythrocytopoiesis}

Is the process of creation of mature erythrocytes from their stem cells by the process of reproduction, maturity and the loss of nucleus and it almost always happens in the bone marrow in the morphological entity of the erythroblastic island.

In order for this process to occur, many factors are needed: normally built bone marrow with all the necessary elements for division and maturity of the erythrocytic cells - Fe, $\mathrm{Cu}$, Co, proteins, vitamins B12, folic acid, appropriate local temperature and normal endocrine regulation.

The first cell of the erythrocytic strain is the proerythroblast, and in this stage of maturity starts the endocytosis of the $\mathrm{Fe}^{3+}$ complex from the extracellular matrix.

With the division of the proerythroblast, the basophilic or early erythroblast is being created. In its ribosomes globin is synthetised, and the synthesis of hem starts in its mitochondrias (11).

Its division creates the polychromatophilic or intermediary erythroblast with visible hemoglobin synthesis.

The acidophilic or orthochromatic erythroblast is the next cell and it contains larger amounts of hemoglobin.

With the ejection of the nucleus from the acidophilic erythroblast, the reticulocyte is created. In this stage, the cells transfer from the bone marrow into the blood stream through the sinusoid capillaries in the process of diapedesis. The endocytosis of iron stops, but synthesis of hemoglobin continues for some time.

A five day period is required for a reticulocyte to get created from the proerythroblast, and another two for it to mature into a full grown erythrocyte.

Erythropoiesis is regulated by the partial pressure of oxygen in the tissues, and the main 
factor which influences the increase of erythropoiesis is erythropoietin - $90 \%$ from the kidneys and $10 \%$ from the liver (12).

The half-life of erythrocytes is $80-120$ days after which they disintegrate, mostly in the liver Kupffer cells and in the spleen, as in the RES macrophage.

Hemoglobin is a protein by nature which can be found in the erythrocytes. It belongs to the class of heteroproteins - apoprotein is a molecule of globin while the prosthetic group is represented by the heme group. Synthesis starts in the proerythroblasts and continues to the reticulocyte and happens in five stages.

In the third stage, the porphyrin IX combines with $\mathrm{Fe}^{2+}$ and heme is created, and in the fourth stage, heme reacts with globin which is made of four peptide chains giving a hemoglobin chain and then the four hemoglobin chains get combined to form hemoglobin.

The largest part of hemoglobin in an adult human (95-98\%) is made of hemoglobin A or adult hemoglobin, while in a much smaller amount there is hemoglobin $A_{2}$ and fetal hemoglobin.

Each molecule of hemoglobin has four atoms of $\mathrm{Fe}$, bound to it are four molecules (8 atoms) of oxygen. The main characteristic of hemoglobin is the ability of reversibility and weak connections with oxygen via coordinative liaisons, in oxyhemoglobin which releases oxygen in the tissues (13).

\section{Iron metabolism regulation}

- There is no physiological excretion of $\mathrm{Fe}$ from the organism.

- From the reason given above, absorption of Fe must be regulated to suit one's daily needs.

- In the case of Fe shortage, the entire amount of the absorbed Fe is given to the transferrin in circulation, and the stored Iron is being released from the storage.

- In the case of Fe surplus, the process is reversed. It is being stored intensively during the increased synthesis of ferritin, and small amounts are bound almost entirely for the saturated transferrin.

- Iron in the enterocytes bound for the ferritin disappears with its desquamation.

- These processes are regulated systematically and on a cell level $(14,15)$.

Pulsation increases as does volume and throbbing volume, renal angiotensin and aldosterone. The artery pressure drops, vascular resistance: systemic $21 \%$, pulmonary $34 \%$. A healthy person resorbs $5-10 \%$ of iron from food.

Food of animal origin has iron in heme form, and of herbal origin has non-heme form of iron.

The resorption of these two types of iron structures is different. It is being resorbed about 20$30 \%$ of heme iron and $2-5 \%$ of non-heme iron. With the consumption of vitamin $\mathrm{C}$, the percentage of adopted non-heme iron is up to $50 \%$.
The consumed Fe is resorbed in the organism in its bivalent form in the duodenum and in the upper jejunum with the help of apoferritin protein which in reverse binds itself to the $\mathrm{Fe}$. As the amount of apoferritin is limited, so is the resorption of $\mathrm{Fe}$ - mucose blockage. The consumed trivalent form and the Fe component bound to heme in the form of $\mathrm{Fe}^{3+}$ must be reduced in its bivalent form with the help of vitamin C. Daily dose of about $1 \mathrm{mg}$ of $\mathrm{Fe}$ is being resorbed which after entering the mucose cells as $\mathrm{Fe}^{2+}$ binds itself to the transportive substances (16).

Before entering the plasma, oxidation in $\mathrm{Fe}^{3+}$ occurs with the help of ceruloplasmin and it ties itself to the transferrin. The Fe serum is almost entirely bound to transferrin. Transferrin-siderophilin is a transporting protein of iron in the plasma and it is coded by the TF gene. It transports iron from the place of absorption to the place of resorption and storage (17).

\section{Two original approaches to anemia diagnostics}

\section{Kinetic approach}

This approach tends to reveal the mechanisms which lead to the anemia. Anemia can appear due to:

\section{Reduced creation of Er}

Reduced creation of $\mathrm{Er}$ occurs if the bone marrow does not create the necessary amount of $\mathrm{Er}$ which would make up for the disintegrated old cells - reduced effective erythropoiesis. It can occur due to: shortage of Fe, vitamin B12 and folic acid; primary disease of the bone marrow; low levels of trophic hormones which stimulate erythropoiesis, such as erythropoietin, the hormones of the thyroid gland and androgens.

2. Accelerated decomposition of $\mathrm{Er}$

Accelerated decomposition of $\mathrm{Er}$ - the normal life span of Er is 120 days, so if it is under 100 days, we are talking about hemolytic anemia.

\section{Loss of Er}

Loss of $\mathrm{Er}$ - bleeding clinically clear due to trauma, melee, hematemesis, menometrorrhagia, ocular, iatrogenesis (18).

\section{Morphological approach}

The erythrocyte index is an important indicator in anemia.

Mean corpuscular volume (MCV) is a crucial factor which determines the morphological division of anemias.

The values of $>115 \mathrm{fL}$ point to megaloblastic anemia determined by shortage of vitamin B12 or folic acid. MCV $<80 \mathrm{fL}$ speaks of microcytic anemia which appears due to Fe loss most commonly.

The morphological approach divides anemias in regard to the size of mid volume erythrocyte MCV and the reticulocyte ratio (19). 


\section{Laboratory analysis}

- Amount of iron bound to the transferrin.

- Amount of iron which can be bound to completely saturated transferrin - Total Iron Binding Capacity (TIBC) and total amount of Fe which can be bound to the apotransferrin is unsaturated or latent capacity of iron binding - unsaturated iron binding capacity (UIBC).

In healthy persons, the percentage of transferrin saturation with iron is $20-40 \%$. A level of saturation of $16 \%$ leads to a drop of erythropoiesis due to reduced capacity of available Fe in the storage depoes, and a saturation under $10 \%$ points to iron deficit in the organism. In case of Fe loss in the storage depoes, its concentration in the plasma also drops while the TIBC value rises, due to the increased synthesis of transferrin.

This parameter is a better indicator of iron deficit than its low concentration.

The sum of serum iron and the UIBC represents the total capacity of iron binding; TIBC is the measure for maximum concentration of Iron which transferrin can bind.

Ferritin level - is a convenient parameter for iron reserves evaluation in the organism and a deficit can be detected in the early stage. Clinically, it is useful to know that the drop in the values under $20 \mathrm{ng} / \mathrm{l}$ points to prelatent deficiency of iron, and if the concentration of ferritin drops under $12 \mathrm{ng} / \mathrm{l}$, this points to complete absence of $\mathrm{Fe}$ in the storage depoes, although the blood count can morphologically still be normal.

Erythrocytic components - are calculated from the Er count, concentration of $\mathrm{Hgb}$ and hematocrit and provide information on the quality of Er.

MCV - average volume of Er, 81-99 fl.

Mean corposcular hemoglobin (MCH) - average amount of $\mathrm{Hb}$ in the erithrocyte, 29-32.9 pg.

Mean corposcular hemoglobin concentration (MCHC) - concentration of $\mathrm{Hb}$ per liter $\mathrm{Er} 310-350$ $\mathrm{g} / \mathrm{l}$.

Red cell distribution width (RDW) - measure variation in size of $\mathrm{Er}, 11.5-19.5 \%$ (20).

Table 1. Red Blood Cell Count (RBC) (whole blood)

\begin{tabular}{||l||c|c|c|c||}
\hline \multicolumn{1}{|c||}{ Units } & $\begin{array}{c}\text { Nonpregnant } \\
\text { Female }\end{array}$ & $\begin{array}{c}\text { First } \\
\text { Trimester }\end{array}$ & $\begin{array}{c}\text { Second } \\
\text { Trimester }\end{array}$ & $\begin{array}{c}\text { Third } \\
\text { Trimester }\end{array}$ \\
\hline \hline $\mathrm{X} 10^{6} / \mathrm{mm}^{3}$ & $4-5.2$ & $3.42-4.55$ & $2.81-4.49$ & $2.72-4.43$ \\
\hline $\mathrm{X} 10^{6} / \mathrm{Ml}$ & $4-5.2$ & $3.42-4.55$ & $2.81-4.49$ & $2.72-4.43$ \\
\hline $\mathrm{X} 10^{12} / \mathrm{L}$ & &
\end{tabular}

Table 2. Hemoglobin (Hgb) (whole blood)

\begin{tabular}{|c||c|c|c|c||}
\hline Units & $\begin{array}{c}\text { Nonpregnant } \\
\text { Female }\end{array}$ & $\begin{array}{c}\text { First } \\
\text { Trimester }\end{array}$ & $\begin{array}{c}\text { Second } \\
\text { Trimester }\end{array}$ & $\begin{array}{c}\text { Third } \\
\text { Trimester }\end{array}$ \\
\hline \hline $\mathrm{g} / \mathrm{dL}$ & $12-15.8$ & $11.6-13.9$ & $9.7-14.8$ & $9.5-15$ \\
\hline $\mathrm{g} / \mathrm{L}$ & $120-158$ & $116-139$ & $97-148$ & $95-150$ \\
\hline
\end{tabular}

Table 3. Total iron-binding capacity (TIBC) (serum)

\begin{tabular}{|c||c|c|c|c||}
\hline Units & $\begin{array}{c}\text { Nonpregnant } \\
\text { Adult }\end{array}$ & $\begin{array}{c}\text { First } \\
\text { Trimester }\end{array}$ & $\begin{array}{c}\text { Second } \\
\text { Trimester }\end{array}$ & $\begin{array}{c}\text { Third } \\
\text { Trimester }\end{array}$ \\
\hline \hline$\mu \mathrm{g} / \mathrm{dL}$ & $228-428$ & $235-408$ & $302-519$ & $380-597$ \\
\hline$\mu \mathrm{mol} / \mathrm{L}$ & $40.8-76.7$ & $42-73$ & $54-93$ & $68-107$ \\
\hline
\end{tabular}

Table 4. Iron (Fe) (serum)

\begin{tabular}{|c||c|c|c|c||}
\hline Units & $\begin{array}{c}\text { Nonpregnant } \\
\text { Adult }\end{array}$ & $\begin{array}{c}\text { First } \\
\text { Trimester }\end{array}$ & $\begin{array}{c}\text { Second } \\
\text { Trimester }\end{array}$ & $\begin{array}{c}\text { Third } \\
\text { Trimester }\end{array}$ \\
\hline \hline$\mu \mathrm{g} / \mathrm{dL}$ & $41-141$ & $72-143$ & $44-178$ & $30-193$ \\
\hline$\mu \mathrm{mol} / \mathrm{L}$ & $7-25$ & $13-26$ & $8-32$ & $5-35$ \\
\hline
\end{tabular}




\section{References}

1. Munro MG, Critchley HOD, Fraser IS; FIGO Menstrual Disorders Committee. The two FIGO systems for normal and abnormal uterine bleeding symptoms and classification of causes of abnormal uterine bleeding in the reproductive years: 2018 revisions. Int J Gynaecol Obstet 2018;143(3):393-408. [CrossRef] [PubMed]

2. Laget $L$, Cortey $A$. Immuno-hematological follow up of pregnant women. Rev Prat 2018;68(5):541-6. [PubMed]

3. Breymann C. Iron Deficiency Anemia in Pregnancy. Semin Hematol 2015;52(4):339-47.

[CrossRef][PubMed]

4. Abbassi-Ghanavati M, Greer LG, Cunningham FG. Pregnancy and laboratory studies: a reference table for clinicians. Obstet Gynecol 2009;114(6):1326-31. [CrossRef][PubMed]

5. Larsson A, Palm M, Hansson LO, Axelsson O. Reference values for clinical chemistry tests during normal pregnancy. BJOG 2008;115(7):874-81. [CrossRef][PubMed]

6. Lockitch G. Handbook of Diagnostic Biochemistry and Hematology in Normal Pregnancy. Boca Raton: CRC; 1993.

7. Kratz A, Ferraro M, Sluss PM, Lewandrowski KB. Laboratory reference values. N Engl J Med 2004; 351(15):1548-63. [CrossRef] [PubMed]

8. James D, Steer P, Weiner C, Gonik B, Crowther C, Robson $\mathrm{S}$ et al. Pregnancy and laboratory studies: a reference table for clinicians. Obstet Gynecol 2010; 115(4):868-69. [CrossRef][PubMed]

9. Wessling-Resnick M. Excess iron: considerations related to development and early growth. Am J Clin Nutr 2017;106(Suppl 6):1600S-1605S. [CrossRef][PubMed]

10. Martínez García RM. Supplements in pregnancy: the latest recommendations. Nutr Hosp 2016;33(Suppl 4):336. [CrossRef][PubMed]

11. McMullin MF, Mead A, Ali S, Cargo C, Chen F, Ewing J et al. A guideline for the management of specific situations in polycythaemia vera and secondary erythro- cytosis: A British Society for Haematology Guideline. $\mathrm{Br}$ J Haematol 2018;184(2):161-75.

[CrossRef][PubMed]

12. McMullin MF, Harrison CN, Ali $S$, Cargo C, Chen F, Ewing $\mathrm{J}$, et al. A guideline for the diagnosis and management of polycythaemia vera. A British Society for Haematology Guideline. $\mathrm{Br}$ ] Haematol 2019; 184(2):176-91. [CrossRef][PubMed]

13. McMullin MF. Investigation and Management of Erythrocytosis. Curr Hematol Malig Rep 2016;11(5):3427. [CrossRef][PubMed]

14. Esen UI. Iron deficiency anaemia in pregnancy: The role of parenteral iron. J Obstet Gynaecol 2017; 37(1):15-18. [CrossRef][PubMed]

15. Cao C, Fleming MD. The placenta: the forgotten essential organ of iron transport. Nutr Rev 2016;74 (7):421-31. [CrossRef][PubMed]

16. Corsini C, Cervi E, Migliavacca F, Schievano S, Hsia TY, Pennati G. Mathematical modelling of the maternal cardiovascular system in the three stages of pregnancy. Med Eng Phys 2017;47:55-63. [CrossRef][PubMed]

17. Grodzinsky A, Florio K, Spertus JA, Daming T, Lee J, Rader $\mathrm{V}$ et al. Importance of the Cardio-Obstetrics Team. Curr Treat Options Cardiovasc Med 2019;21 (12):84. [CrossRef][PubMed]

18. Sun D, McLeod A, Gandhi S, Malinowski AK, Shehata N. Anemia in Pregnancy: A Pragmatic Approach. Obstet Gynecol Surv 2017;72(12):730-7. [CrossRef][PubMed]

19. Anchang-Kimbi JK, Nkweti VN, Ntonifor HN, Apinjoh TO, Chi HF, Tata RB et al. Profile of red blood cell morphologies and causes of anaemia among pregnant women at first clinic visit in the mount Cameroon area: a prospective cross sectional study. BMC Res Notes 2017;10(1):645. [CrossRef] [PubMed]

20. Crispin PJ, Sethna F, Andriolo K. Red Cell and Reticulocyte Parameters for the detection of Iron Deficiency in Pregnancy. Clin Lab 2019;65(11).

[CrossRef][PubMed] 


\title{
ANEMIJE U GINEKOLOGIJI I PERINATOLOGIJI - NOVI STAVOVI
}

\author{
Dragana Radović-Janošević1,2, Hristina Čolović ${ }^{3,4}$, Jelena Milošević-Stevanović ${ }^{1,2}$, \\ Jelena Seratlić1,2, Dane Krtinić5,6
}

\begin{abstract}
${ }^{1}$ Univerzitet u Nišu, Medicinski fakultet, Katedra za ginekologiju i akušerstvo, Niš, Srbija ${ }^{2}$ Klinika za ginekologiju i akušerstvo, Klinički centar Niš, Niš, Srbija

3Univerzitet u Nišu, Medicinski fakultet, Katedra za fizikalnu medicinu i rehabilitaciju, Niš, Srbija

${ }^{4}$ Klinika za fizikalnu medicinu i rehabilitaciju, Klinički centar Niš, Niš, Srbija

5Univerzitet u Nišu, Medicinski fakultet, Katedra za farmakologiju sa toksikologijom, Niš, Srbija

${ }^{6}$ Klinika za onkologiju, Klinički centar Niš, Niš, Srbija
\end{abstract}

Kontakt: Dane Krtinić

Bulevar dr Zorana Đinđića 81, 18000 Niš, Srbija

E-mail: dane.krtinic@medfak.ni.ac.rs

Anemija predstavlja globalni zdravstveni problem. Među ženama zastupljena je kod $38 \%$ trudnica i $29 \%$ negravidnih žena. Najčešći oblik je sideropenijska anemija. Najčeći uzrok anemije u ginekologiji su abnormalna materična krvarenja, koja se javljaju kao akutno, hronično i intermitentno krvarenje. $U$ perinatologiji postoje specifične promene na nivou kardiovaskularnog i hematopoetskog sistema trudnice, koje nameću različite kriterijume za dijagnozu anemije u odnosu na negravidno stanje. Osnovna promena je porast volumena krvi, koji raste više na račun plazme, spram volumena eritrocita. Volumen eritrocita raste za oko 33\%, a takođe raste i broj retikulocita. Dva su osnovna pristupa dijagnostici anemije kinetički pristup, koji nastoji da utvrdi mehanizam koji je do anemije doveo i morfološki pristup, koji deli anemije u odnosu na veličinu srednjeg volumena eritrocita i retikulocitnog odgovora. Terapija najčešće, sideropenijske, anemije vrši se preparatima gvožđa (hemsko, dvovalentno i trovalentno gvoždje). U trudnoći, ono je potrebno svim trudnicama, ali samo u umerenim dozama. Ukupno antenatalno povećanje treba da iznosi oko $1000 \mathrm{mg}$. Da bi se ove potrebe zadovoljile, u prvoj polovini trudnoće potrebno je 4 mg gvožđa dnevno, a u drugoj polovini od $6 \mathrm{mg}$ do $7 \mathrm{mg}$. Zbog lošeg podnošenja gvožđa, komplijansa njegove primene procenjuje se na $50 \%$.

Acta Medica Medianae 2020;59(3):84-89.

Ključne reči: anemije, ginekologija, perinatologija 